\title{
HUBUNGAN ASUPAN KARBOHIDRAT DAN STATUS GIZI DENGAN TINGKAT KEBUGARAN JASMANI PADA ATLET BASKET REMAJA SISWA SEKOLAH MENENGAH PERTAMA
}

\author{
Haidar Rizqi ${ }^{1}$, Ichwanudin ${ }^{2}$ \\ ${ }^{1}$ Program Studi Diploma III, Jurusan Gizi, Poltekkes Kemenkes Bandung \\ ${ }^{2}$ Jurusan Gizi, Poltekkes Kemenkes Bandung \\ Email : hdrrizqi@gmail.com
}

\begin{abstract}
ABSTRAK
Kebugaran jasmani yang baik pada atlet sangat penting agar tampil maksimal saat pertandingan. Faktor yang mempengaruhi kebugaran jasmani diantaranya adalah asupan gizi, status gizi dan usia. Usia remaja memerlukan asupan gizi yang cukup untuk pertumbuhan dan menjalankan aktifitas fisiknya dalam kehidupan sehari-hari. Peran karbohidrat dalam olahraga sangat penting yaitu sebagai cadangan glikogen otot saat berolahraga. Tujuan penelitian ini adalah menganalisis hubungan asupan karbohirat, status gizi dengan kebugaran jasmani pada atlet basket remaja Sekolah Menengah Pertama. Penelitian ini menggunakan desain penelitian cross sectional. Besar sampel dalam penelitian ini menggunakan total populasi sebanyak 37 orang yang merupakan anggota tim basket di SMPN 2 Ngamprah Kabupaten Bandung Barat. Pengumpulan data asupan karbohidrat diperoleh melalui metode semi quantitative food frequency questionnaire. Status gizi diperoleh dengan mengukur berat badan menggunakan alat timbangan injak digital dan mengukur tinggi badan menggunakan alat microtoise. Rata-rata asupan karbohidrat responden sebesar 375,4 gram dimana sebanyak 29,7\% memiliki asupan karbohidrat kurang dan 70,3\% termasuk kategori asupan karbohidrat baik. Rata-rata z-score IMT/U -0,166 SD. Sebanyak 2,7\% termasuk sangat kurus, 5,4\% kurus, 70,3\% normal, 13,5\% gemuk dan 8,1\% obesitas. Rata-rata skor kebugaran sebesar 14,9 (range 5-20), artinya rata-rata termasuk kategori baik. Sebanyak 13,5\% termasuk kategori kurang dan 86,5\% termasuk kategori baik. Hasil uji statistik Spearman Rank Test menunjukkan terdapat hubungan antara asupan karbohidrat $(\mathrm{p}=0,038$ dan $\mathrm{r}=0,342)$ dan status gizi $(\mathrm{p}=0,025$ dan $\mathrm{r}=-0,367)$ dengan tingkat kebugaran. Kesimpulan dari penelitian ini adalah asupan karbohidrat dan status gizi berhubungan dengan kebugaran jasmani atlet basket remaja. Atlet basket remaja disarankan untuk mencukupi asupan karbohidrat dan menjaga status gizinya pada kategori normal agar memiliki kebugaran jasmani yang baik.
\end{abstract}

Kata kunci: karbohidrat, kebugaran jasmani, status gizi

\begin{abstract}
Good physical fitness in athletes is essential in order to reach maximum performance during the game. Factors which affect the physical fitness are nutrition intake, nutritional status dan age. The role of carbohydrates in sports is very important to spare muscle glycogen during exercise. This study purpose was to analyze the correlation between carbohydrate intake, nutritional status and physical fitness in adolescent athletes of junior high school. This study used a cross-sectional study design. Total subjects in this study using a total population of about 37 people who are members of basketball team in junior high school 2 Ngamprah West Bandung District. Data of Carbohydrate intake was obtained through semi quantitative food frequency questionnaire method. Nutritional status was obtained by measuring body weight using digital bathroom scales and measuring height using microtoise tools. The average intake of carbohydrates was 375.4 grams which was $29.7 \%$ have a less carbohydrate intake and $70.3 \%$ have a adequate carbohydrate intake, average BMI for age z-score was -0.166 SD as much as $2.7 \%$ have a very thin nutritional status, $5.4 \%$ have a thin nutritional status, $70.3 \%$ have a normal nutritional status, $13.5 \%$ overweight and $8.1 \%$ obese. The average fitness score was 14.9 (range 5-20) that means average they have a good physical fitness which was as much as $13.5 \%$ have a lack physical fitness and $86.5 \%$ have a good physical fitness. Results revealed that there is correlation between carbohydrate intake and physical fitness ( $p=0.025$ and $r=-0.367)$, nutritional status and physical fitness ( $p=0.038$ and $r=0.342$ ). The conclusion of this study is carbohydrate intake and nutritional status related to the physical fitness of adolescence basketballs athletes. Adolescent basketball athletes are advised to provide carbohydrate intake and maintain their nutritional status in the normal category in order to have good physical fitness.
\end{abstract}

Keywords: carbohydrate, nutritional status, physical fitness 


\section{PENDAHULUAN}

Kebugaran terdiri dari kemampuan motorik dan faktor-faktor yang mempengaruhi kesehatan karena terdiri dari daya tahan kardiorespirasi, kekuatan otot, komposisi tubuh dan fleksibilitas/ kelentukan tubuh (Sawada, 2014). Kebugaran memiliki kelebihan jika seseorang mampu meningkatkannya, yaitu dapat meningkatkan status kesehatan. Meskipun kebugaran merupakan bawaan dari keturunan, namun dapat ditingkatkan dengan cara latihan (Sharkey, et al., 2007).

Dari konsep kebugaran jasmani, setiap orang membutuhkan kebugaran jasmani berbedabeda, tergantung dari sifat tantangan fisik yang dihadapinya. Kebugaran jasmani akan meningkat apabila kekuatan otot, daya tahan otot dan daya tahan kardiovaskular-respiratory meningkat yang disebabkan oleh aktivitas fisik. Kebugaran jasmani adalah kemampuan tubuh beradaptasi dengan lingkungan dan kerja fisik yang dilakukan (Awisaba, 2014). Unsur kebugaran yang termasuk dalam permainan basket adalah keseimbangan (balance), kelincahan (agility), kekuatan (strength), kecepatan gerak dan reaksi (speed), daya tahan otot dan kardiovaskuler (endurance), kelentukan (flexibility) dan koordinasi (coordination) (Faruq, 2008). Atlet basket yang memiliki kebugaran baik dapat melempar (shooting) bola dengan jarak yang lebih jauh karena memiliki kekuatan otot yang baik (Pojskić, et al., 2014)

Remaja yang beranjak dewasa memiliki beberapa masalah kesehatan yang kronis. Ketika beranjak dewasa banyak remaja yang mengembangkan pola makan yang tidak baik, seperti tidak sarapan, makan tidak teratur, dan terlalu banyak mengonsumsi makanan ringan sebagai sumber makanan sehari-hari. Ada pula yang berlebihan pola makannya, sering merokok, tidak berolahraga, dan hanya tidur selama beberapa jam di malam hari. Gaya hidup seperti ini dapat berdampak buruk terhadap kesehatan. Kebutuhan gizi yang direkomendasikan untuk dikonsumsi oleh remaja perlu ditimbangkan secara individual berdasarkan tingkat pertumbuhan dan aktivitas fisiknya, serta usia dan jenis kelamin mereka. Sebagai contoh laki-laki membutuhkan energi lebih besar dibandingkan dengan perempuan (Santrock, 2007). Remaja cenderung memiliki sifat yang konsumtif serta memiliki pola konsumsi yang tidak beraturan karena pada masa ini remaja sedang mengalami tahap pertumbuhan sehingga cenderung memilih makanan yang menggugah selera serta biasanya memiliki kadar glukosa dan lemak yang cukup tinggi. Jenis makanan inilah yang berdampak pada berat badan berlebih dan memicu munculnya penyakit degeneratif seperti diabetes mellitus (Marine, 2015)

Kebutuhan energi dan zat gizi bagi atlet perlu memperhatikan jenis olahraganya. Selain itu, perlu diperhatikan tahapan-tahapan dalam pemenuhan gizi pada atlet seperti pemenuhan gizi untuk periode latihan, kompetisi dan pemulihan. Hal lain yang perlu diperhatikan adalah variasi makanan, kesukaan dan daya terima atlet agar asupannya sesuai dengan kebutuhan atlet. Pada olahraga permainan seperti bola basket makanan yang dikonsumsi atlet harus mengandung 50-60\% karbohidrat, $30-35 \%$ lemak dan $12-15 \%$ protein (Kemenkes RI, 2014)

Asupan karbohidrat sangat penting bagi seorang atlet untuk mempertahankan cadangan energi yang cukup dengan memastikan bahwa cadangan glikogen terisi sebanyak mungkin. Hal ini dapat tercapai dengan asupan karbohidrat yang adekuat (Barasi, 2009).

Kebugaran jasmani dan status gizi yang tidak seimbang pada remaja dapat menyebabkan terjadinya gangguan perkembangan dan pertumbuhan, karena manusia setiap kali melakukan gerak memerlukan energi, dan energi yang digunakan untuk melakukan gerak berasal dari makanan yang cukup mengandung nilai gizi yang baik. Hal tersebut membuat remaja akan terlihat semangat, gesit, dan aktif dalam melakukan gerak atau aktivitas, sehingga dapat meningkatkan daya tahan otot, kelentukan, koordinasi dan kelincahan gerak yang baik. Berdasarkan hasil penelitian Sugandhi (2012) terdapat hubungan yang signifikan antara status gizi dengan tingkat kebugaran jasmani siswa Sekolah Menengah Kejuruan YPLP Perwira Purbalingga.

Hasil survey tim pengembang Sport Development Index meneliti kebugaran jasmani pada pelajar SD, SMP dan SMA di seluruh Indonesia pada kelompok yang tidak terlatih (bukan atlet). Hasilnya adalah baik 5,7\%, sedang 
$37,7 \%$, kurang $46,0 \%$, kurang sekali $10,7 \%$ (Kahri, 2011). Tujuan utama penelitian ini adalah menganalisis hubungan antara asupan karbohidrat, status gizi dan tingkat kebugaran pada siswa sekolah menengah pertama.

\section{METODE}

Penelitian ini menggunakan desain penelitian cross sectional yang dilakukan di SMPN 2 Ngamprah, Kabupaten Bandung Barat, pada bulan Februari 2014. Sampel pada penelitian ini merupakan total populasi sebanyak 37 orang yang merupakan anggota tim basket di SMPN 2 Ngamprah, Kabupaten Bandung Barat. Data identitas pribadi didapatkan dari kuesioner yang telah disusun. Berat badan diukur menggunakan timbangan injak digital dengan ketelitian $0,1 \mathrm{~kg}$. Tinggi badan diukur menggunakan alat microtoise dengan ketelitian $0,1 \mathrm{~cm}$. Asupan karbohidrat didapatkan dari wawancara asupan makanan 1 bulan terakhir menggunakan semi quantitative food frequency questionnaire yang telah ditambahkan bahan makanan berupa jajanan yang berada di kantin maupun jajanan sekitar sekolah melalui survey pendahuluan. Status gizi menggunakan IMT yang didapatkan dari rumus:

$$
\mathrm{IMT}=\frac{B B(\mathrm{~kg})}{\{T B(m)\}^{2}}
$$

Hasilnya dimasukkan dalam aplikasi $\mathrm{WHO}$ Anthro Plus 2007 untuk mendapatkan nilai z-score IMT/U dan dikategorikan berdasarkan kategori ambang batas status gizi anak berdasarkan indeks massa tubuh (IMT) menurut umur anak usia 5-18 tahun (Kemenkes, 2010). Kebugaran jasmani diukur melalui 3 tahap tes yaitu: tes daya tahan jantung paru dengan metode Harvard step stest selama 5 menit. Jika responden tidak kuat melakukan tes selama 5 menit maka dicatat waktu yang ditempuh oleh responden saat berhenti, kemudian diukur denyut nadi sampel pada 30 detik pertama, 30 detik kedua dan 30 detik ketiga (dengan jeda waktu seminimal mungkin), kemudian dihitung berdasarkan rumus :

$$
\frac{\text { waktu dalam detik } \times 100}{2 \times(\text { denyut nadi ke } 1+\text { ke } 2+\text { ke } 3)}
$$

hasil dari perhitungan tersebut kemudian dikategorikan menjadi skor 1-5. Skor $1=$ sangat kurang $(<50), 2=$ kurang (50-64), $3=$ cukup $(65$ $79), 4=$ baik (80-89) dan 5 = sangat baik $(>90)$. Tes kedua adalah tes daya tahan kekuatan otot menggunakan metode push up dan sit up masingmasing dilakukan selama 1 menit kemudian hasil yang dicapai dikategorikan berdasarkan skor 1-5 (1= sangat kurang, $2=$ kurang, $3=$ cukup, $4=$ baik dan 5 = sangat baik) sesuai dengan jenis kelamin sampel, kategori penilaian dapat dilihat pada tabel 1.

Tes terakhir adalah kelentukan tubuh (flexibility) dengan metode mengaitkan tangan di belakang punggung, kemudian hasilnya dikategorikan berdasarkan skor 1-5 (1= sangat kurang, $2=$ kurang, $3=$ cukup, $4=$ baik dan 5 = sangat baik), skor 5: kedua tangan bersalaman sempurna, skor 4: semua jari kedua tangan bertemu, skor 3: kedua tangan bersentuhan sedikit , skor 2: hanya 1 jari yang saling bersentuhan dan skor 1 :kedua tangan tidak saling bertemu. Total skor dari ketiga tes (daya tahan jantung paru, daya tahan kekuatan otot dan kelentukan tubuh) merupakan total skor kebugaran. Kebugaran baik apabila total skor kebugaran 13-20 dan kebugaran kurang apabila total skor kebugaran $<13$ (Suntoda, 2009).

Analisis data yang dilakukan pada penelitian ini terdiri dari analisis univariat dan bivariat. Analisis univariat dilakukan untuk menyajikan data secara deskriptif dengan tabel distribusi frekuensi, sedangkan analasis hubungan antar

Tabel 1. Kategori Push Up dan Sit Up Selama 1 Menit Berdasarkan Jenis Kelamin

\begin{tabular}{lcc}
\hline \multicolumn{1}{c}{ Kategori (skor) } & Push $\boldsymbol{U p}$ & Sit $\boldsymbol{U p}$ \\
\hline Laki-Laki & & \\
- Baik Sekali (5) & $\geq 39$ & $\geq 48$ \\
- Baik (4) & $29-38$ & $42-47$ \\
- Cukup (3) & $23-28$ & $38-41$ \\
- Kurang (2) & $19-22$ & $33-37$ \\
- Kurang sekali (1) & $\leq 17$ & $\leq 32$ \\
Perempuan & & \\
- Baik Sekali (5) & $\geq 33$ & $\geq 42$ \\
- Baik (4) & $25-32$ & $36-41$ \\
- Cukup (3) & $18-24$ & $31-35$ \\
- Kurang (2) & $12-17$ & $27-30$ \\
- Kurang sekali (1) & $\leq 11$ & $\leq 26$ \\
\hline
\end{tabular}


variabel menggunakan uji korelasi Spearman Rank Test dengan tingkat kepercayaan $95 \%$.

\section{HASIL DAN PEMBAHASAN}

Tim basket SMPN 2 Ngamprah atau yang lebih sering disebut dengan tim "SHELTER" berlatih di lingkungan sekolah dengan fasilitas lapangan basket yang ada. Latihan dilakukan setiap hari sepulang sekolah dengan durasi selama 3 jam yaitu dimulai pukul 14.00-17.00 pada hari senin hingga jum'at. Pada hari Sabtu dan Minggu latihan dilakukan lebih awal dengan durasi yang lebih lama yaitu selama 6 jam pada pukul 09.0015.00. Terdapat 3 sesi latihan, yaitu pemanasan, latihan fisik dan latihan permainan bola basket seperti shooting, dribble, lay up shoot dan simulasi pertandingan.

Responden terbanyak dalam penelitian ini berdasarkan jenis kelamin adalah perempuan (56,8\%), dengan usia terbanyak berada pada usia 14 tahun $(40,5 \%)$ dan rata-rata usia seluruh responden sebesar 13,9 tahun. Seluruh responden termasuk dalam usia remaja. Hal ini selaras dengan Kemenkes RI nomor 25 yang menyatakan bahwa usia remaja adalah kelompok usia 10-18 tahun (Kemenkes RI, 2014).

Berdasarkan hasil penelitian, kebugaran pada laki-laki lebih baik dibandingkan pada perempuan, yaitu sebanyak $87,5 \%$ responden laki-laki memiliki kebugaran baik, sedangkan pada responden perempuan sebanyak $85,7 \%$ yang memiliki kategori kebugaran yang baik (Tabel 3). Hal ini sesuai dengan salah satu faktor yang mempengaruhi kebugaran yaitu jenis kelamin, dimana setelah puber, tingkat kebugaran anak perempuan jauh tertinggal dari anak laki-laki yang

Tabel 2. Distribusi Responden Berdasarkan Karakteristik

\begin{tabular}{lr}
\hline Karakteristik Responden & Jumlah \\
\cline { 2 - 2 } Jenis Kelamin & $\mathbf{n}(\%)$ \\
- Laki-laki & \\
- Perempuan & $16(43,2)$ \\
Usia Responden & $21(56,8)$ \\
- 12 tahun & \\
-13 tahun & $2(5,4)$ \\
-14 tahun & $14(37,8)$ \\
-15 tahun & $15(40,5)$ \\
\hline
\end{tabular}

disebabkan oleh perbedaan jumlah hemoglobin, besarnya otot, dan kandungan lemak. Perempuan memiliki masa otot lebih kecil dan umumnya perempuan memiliki kandungan lemak tubuh lebih banyak dibanding pada laki-laki (Musrifah, 2012). Hasil dari tes kebugaran jantung paru didapatkan hasil sebanyak $73 \%$ responden memiliki skor 5 (baik sekali), artinya dengan kemampuan daya tahan jantung paru yang baik kemampuan responden untuk melakukan suatu pekerjaan dalam waktu relatif lama dan beban sub maksimal, dengan intensitas latihan yang konstan tergolong baik atau dengan kata lain tidak mudah mengalami kelelahan saat bertanding dengan intensitas latihan/ olahraga yang konstan. Hasil daya tahan otot sit up sebanyak 48,6\% responden memiliki skor 4 (Baik) dan 29,7\% memiliki skor 5 (sangat baik), artinya kemampuan otot dan atau sekelompok otot untuk

Tabel 3. Hasil Tes Kebugaran Berdasarkan Skor

\begin{tabular}{lr}
\hline Tes Komponen Kebugaran & n (\%) \\
\hline Daya Tahan Jantung Paru & \\
- Skor 5 & $27(73,0)$ \\
- Skor 4 & $1(2,7)$ \\
- Skor 3 & $7(18,9)$ \\
- Skor 2 & $0(0,0)$ \\
- Skor 1 & $2(5,4)$ \\
Daya Tahan Otot sit up & \\
- Skor 5 & $11(29,7)$ \\
- Skor 4 & $18(48,6)$ \\
- Skor 3 & $7(18,9)$ \\
- Skor 2 & $0(0,0)$ \\
- Skor 1 & $1(2,7)$ \\
Daya Tahan Otot push up & \\
- Skor 5 & $6(16,2)$ \\
- Skor 4 & $2(5,4)$ \\
- Skor 3 & $4(10,8)$ \\
- Skor 2 & $7(18,9)$ \\
- Skor 1 & $18(48,6)$ \\
Kelentukan (flexibility) & \\
- Skor 5 & $12(32,4)$ \\
- Skor 4 & $19(51,4)$ \\
- Skor 3 & $4(10,8)$ \\
- Skor 2 & $2(5,4)$ \\
- Skor 1 & $0(0)$ \\
\hline Hasil Tes Kebugaran & $\mathbf{\%}$ \\
\hline Kurang & \\
Laki-laki & 12,5 \\
Perempuan & 17,3 \\
Baik & \\
Laki-laki & 87,5 \\
Perempuan & 85,7 \\
\hline & \\
\hline & \\
\hline & \\
\hline
\end{tabular}


berkontraksi secara sub maksimal dan berulangulang dalam jangka waktu tertentu khususnya otot perut sebagian besar responden tergolong baik. Hasil dari tes push up sebanyak 48,6\% responden memiliki skor 1 (sangat kurang), dan $18,9 \%$ memiliki skor 2 (kurang), artinya sebagian besar responden memiliki kemampuan otot dan atau sekelompok otot untuk berkontraksi secara sub maksimal dan berulang-ulang dalam jangka waktu tertentu dalam hal ini adalah otot lengan (bisep dan trisep) sebagian besar sampel tergolong sangat kurang. Hal ini bisa disebabkan karena olahraga basket bukan merupakan jenis olahraga yang mutlak memerlukan kekuatan otot lengan, tidak seperti olahraga angkat beban yang mutlak membutuhkan kekuatan otot di lengan. Hasil tes kelentukan tubuh (flexibility) sebanyak 51,4\% responden memiliki skor 4 (baik) dan 32,4\% memiliki skor 5 (sangat baik) artinya kemampuan responden untuk menggerakkan tubuh dan bagianbagian tubuh dalam satu ruang gerak yang seluas mungkin tanpa mengalami cedera pada persendian dan otot di sekitar persendian, atau dengan kata lain "luasnya ruang gerak persendian" dapat dikatakan baik. Hal ini dikarenakan olahraga basket memerlukan kelenturan yang baik untuk melewati lawan-lawannya saat di pertandingan sehingga dapat men-dribble bola secara leluasa setelah melewati lawannya.

Tabel 4 menunjukkan bahwa pada responden dengan asupan karbohidrat baik sebanyak 64,9\% responden memiliki kebugaran yang baik. Pada responden dengan asupan karbohidrat kurang, hanya menunjukkan $21,6 \%$ responden yang memiliki kebugaran baik, dan $8,1 \%$ memiliki kebugaran yang kurang. Rata-rata asupan karbohidrat sehari seluruh responden sebesar 375,42 gram/hari. Hal ini menunjukkan bahwa sebagian besar responden tercukupi kebutuhan asupan karbohidrat per harinya. Hasil tersebut lebih tinggi dibandingkan dengan rata-rata kebutuhan karbohidrat berdasarkan jenis aktivitas fisik responden yakni 333 gram/hari.

Hasil analisis statistik menunjukkan bahwa ada hubungan positif antara asupan karbohidrat dengan tingkat kebugaran dengan keeratan hubungan sedang (Tabel 4). Hal ini menunjukkan semakin tinggi asupan karbohidrat maka semakin tinggi pula skor kebugaran. Tabel 4 menunjukkan bahwa responden dengan asupan karbohidrat baik memiliki kebugaran yang baik dibandingkan pada responden dengan asupan karbohidrat kurang, yang berarti bahwa responden dengan asupan karbohidrat sesuai kebutuhan memiliki kebugaran yang lebih baik dibandingkan pada responden dengan asupan karbohidrat yang kurang dari kebutuhan. Jenis karbohidrat yang sangat diperlukan untuk atlet adalah glukosa yang merupakan monosakarida paling penting, karena sebagian besar karbohidrat dipecah menjadi glukosa dalam darah. Glukosa yang masuk ke dalam aliran darah dapat diubah menjadi glikogen di hati dan otot, dan jumlah glukosa yang berlebih akan diserap dan diubah menjadi asam lemak dan trigliserida dalam hati dan jaringan adiposa. Selain itu, kadar glukosa darah harus dipertahankan selama latihan endurance. Asupan karbohidrat yang rendah akan mengakibatkan penggunaan glikogen hati dan otot dengan cepat sehingga berdampak pada latihan anaerobik atau

Tabel 4. Hubungan Asupan Karbohidrat, Status Gizi dan Tingkat Kebugaran

\begin{tabular}{|c|c|c|c|c|c|c|c|c|}
\hline \multirow{3}{*}{ Variabel } & \multicolumn{4}{|c|}{ Kategori Kebugaran } & \multirow{2}{*}{\multicolumn{2}{|c|}{ Total $(\mathbf{N}=\mathbf{3 7})$}} & \multirow{2}{*}{\multicolumn{2}{|c|}{ Hasil Uji }} \\
\hline & \multicolumn{2}{|c|}{ Kurang $(n=5)$} & \multicolumn{2}{|c|}{ Baik (n=32) } & & & & \\
\hline & $\mathbf{n}$ & $\%$ & $\mathbf{n}$ & $\%$ & $\mathbf{n}$ & $\%$ & p-value & $\mathbf{r}$ \\
\hline \multicolumn{9}{|c|}{ Asupan Karbohidrat } \\
\hline - Kurang & 3 & 8,1 & 8 & 21,6 & 11 & 29,7 & \multirow{2}{*}{0,038} & \multirow{2}{*}{0,342} \\
\hline - Baik & 2 & 5,4 & 24 & 64,9 & 26 & 70,3 & & \\
\hline \multicolumn{9}{|l|}{ Status Gizi (IMT/U) } \\
\hline - Sangat Kurus & 0 & 0 & 1 & 2,7 & 1 & 2,7 & \multirow{5}{*}{0,025} & \multirow{5}{*}{$-0,367$} \\
\hline - Kurus & 0 & 0 & 2 & 5,4 & 2 & 5,4 & & \\
\hline - Normal & 2 & 5,4 & 24 & 64,9 & 26 & 70,3 & & \\
\hline - Gemuk & 2 & 5,4 & 3 & 8,1 & 5 & 13,5 & & \\
\hline - Obesitas & 1 & 2,7 & 2 & 5,4 & 3 & 8,1 & & \\
\hline
\end{tabular}


aerobik pada intensitas tinggi dan durasi yang lama dan akan mengakibatkan tidak terpenuhinya karbohidrat bagi atlet. Oleh karena itu, pemenuhan asupan karbohidrat bagi atlet sangat dibutuhkan baik sebelum latihan maupun saat bertanding dengan tujuan untuk mengisi simpanan glikogen pada otot dan hati (Roscamp dan Santos, 2015). Tabel 4 menunjukkan bahwa responden dengan status gizi gemuk dan obesitas cenderung memiliki kategori kebugaran yang kurang. Pada responden dengan status gizi normal sebagian besar memiliki kebugaran yang baik. Analisis statistik menunjukkan ada hubungan negatif antara status gizi IMT/U dengan tingkat kebugaran dengan keeratan sedang (Tabel 4). Hubungan semakin tinggi nilai $z$-score IMT/U maka semakin rendah skor kebugaran. Hal ini sesuai dengan penelitian yang dilakukan Muizzah yang menunjukkan bahwa hubungan antara IMT dengan kebugaran jasmani terdapat hubungan negatif, yang artinya semakin bertambahnya atau meningkatnya nilai IMT maka akan semakin bertambah denyut nadi yang berarti tingkat kebugarannya semakin berkurang (Muizzah, 2013). Berdasarkan penelitian Pahkala dkk menunjukkan bahwa pada anak dengan IMT yang rendah secara konsisten selama 4 tahun berturut-turut (pada usia 13 hingga 17 tahun) memiliki kebugaran yang lebih baik dibandingkan pada anak yang mengalami peningkatan IMT selama 4 tahun atau memiliki IMT yang tinggi selama 4 tahun (pada usia yang sama) (Pahkala, dkk., 2011). IMT yang berlebih dapat disebabkan oleh berat badan yang berlebih karena akumulasi lemak yang berlebihan atau memiliki massa otot yang tinggi, karena komposisi tubuh manusia terdiri dari 3 komponen yaitu lemak, otot dan tulang, ketiga komponen tubuh tersebut dapat terjadi peningkatan atau penurunan karena bersifat fluktuatif, apabila salah satu komponen tubuh tersebut menurun maka komponen tubuh lain akan menggantikan agar komposisi tubuh tetap seimbang. Saat terjadi peningkatan berat badan yang disebabkan oleh peningkatan lemak pada tubuh seseorang akan menyebabkan menurunnya massa otot, begitupun sebaliknya pada saat terjadi peningkatan massa otot akan terjadi penurunan lemak di dalam tubuh (Kumar, 2016). Karbohidrat disimpan dalam bentuk glikogen di dalam otot dan hati, maka apabila massa otot rendah dapat mempengaruhi jumlah glikogen yang tersimpan.

Menurunnya ketersediaan glukosa darah akan menurunkan penyerapan dan oksidasi karbohidrat pada otot, pada saat yang sama akan terjadi meningkatkan oksidasi lemak (Williams dan Rollo, 2015). Terjadinya peningkatan oksidasi lemak disebabkan oleh adaptasi enzim oksidatif di sel otot. Hal ini menyebabkan kadar glikogen dan oksidasi dari otot menurun (Putri, 2015). Apabila IMT seseorang tinggi yang disebabkan oleh komposisi lemak dalam tubuh seseorang lebih tinggi dibandingkan massa ototnya, maka akan menurunkan cadangan glikogen dalam tubuh.

Keterbatasan dalam penelitian ini adalah tidak melihat komposisi tubuh seperti massa otot dan lemak tubuh dimana keduanya merupakan komponen dari berat badan seseorang, sehingga nilai IMT yang tinggi tetap dikategorikan overweight atau obesitas pada penelitian ini.

\section{KESIMPULAN DAN SARAN}

Kesimpulan yang bisa didapatkan dari penelitian ini adalah terdapat hubungan positif antara asupan karbohidrat dengan tingkat kebugaran, Sebaliknya terdapat hubungan negatif antara status gizi dengan tingkat kebugaran. Perlunya mengonsumsi asupan karbohidrat sesuai kebutuhan dan menjaga status gizi pada nilai normal agar memiliki kebugaran jasmani yang baik.

\section{DAFTAR PUSTAKA}

Awisaba, Robertus E. (2014). Hubungan antara status gizi dengan tingkat kebugaran jasmani tim futsal putra O2SN SMK Daerah Istimewa Yogyakarta Tahun 2014 (Skripsi, Universitas Negeri Yogyakarta, Yogyakarta). Diakses dari http://eprints.uny.ac.id/15800/

Barasi, Mary E. (2009). At a glance ilmu gizi. Jakarta: Erlangga.

Faruq, M.Muhyi. (2008). Meningkatkan kebugaran jasmani melalui permainan dan olahraga bola basket.Jakarta: PT Grasindo.

Kahri, M. (2011). Pengaruh pendidikan jasmani melalui aktivitas bermain terhadap kebugaran jasmani, perkembangan kemampuan fisik anak dayak loksado dengan anak Kota Banjarmasin 
Kalimantan Selatan. Jurnal Universitas Pendidikan Indonesia edisi khusus no. 1

Kemenkes RI.(2010). Keputusan Menteri Kesehatan Republik Indonesia.No.1995/Menkes/SK/ XII/2010 tentang standar antropometri penilaian status gizi anak. Jakarta.

Kemenkes RI .(2014). Peraturan Menteri Kesehatan Republik Indonesia nomor 25 Tahun 2014 tentang upaya kesehatan anak. Jakarta.

Kumar, Dinesh. (2016). Relationship between body fat and skeletal muscle mass. International Journal of Physical Education, Sports and Health, 3(4), 203-204.

Marine, Denov. (2015). Perbedaan pola konsumsi dan status gizi antara remaja dengan orang tua diabetes mellitus (DM) dan Non DM. Jurnal Media Gizi Indonesia 10(2), 179-183.

Muizzah, Lilik. (2013). Hubungan antara kebugaran dengan status gizi dan aktivitas fisik pada mahasiswi Program Studi Kesehatan Masyarakat UIN Syarif Hidayatullah Jakarta Tahun 2013. (Skripsi, UIN Syarif Hidayatullah Jakarta). Diakses dari http: //repository.uinjkt. ac.id/ dspace/ handle/ 123456789/26503.

Musrifah, Ani. (2012). Pengaruh senam Indonesia Sehat terhadap tingkat kesegaran jasmani siswa kelas IV Sekolah Dasar Brajan, Kecamatan Pleret, Kabupaten Bantul Daerah Istimewa Yogyakarta (Skripsi, Universitas Negeri Yogyakarta, Yogyakarta). Diakses dari http:// eprints.uny.ac.id/8762/.

Pahkala, K., Hernelahti, M., Heinonen, O.J., Raittinen, P., Hakanen, M., Lagström, H., Viikari, J.S., Rönnemaa, T., Raitakari, O.T., Simell, O. (2013). Body mass index, fitness and physical activity from childhood through adolescence. British Journal of Sports Medicine, 47(2), 71-77. doi:dx.doi.org/10.1136/bjsports2011-090704.

Pojskić, H., Šeparović, V., Muratović, M., Užičanin, E. (2014). The relationship between physical fitness and shooting accuracy of professional basketball players. Motriz, Rio Claro 20(4), 408-417. doi: dx.doi.org / 10.1590/ S1980657420140004000007.

Putri, Tri Oktariani. (2015). Proses konversi makanan sebagai sumber energi. Diakses dari http://www.apki.or.id/proses-konversi-makanan - sebagai-sumber-energi /.

Roscamp R, Santos MG. (2015). Effects of carbohydrates supplementation and physical exercise. J Nutr Health Sci, 2(3), 303 . doi: 10.15744/2393-9060.2.303.

Santrock, John W. (2007). Remaja. (Edisi 11, jilid 2). Jakarta: Erlangga.

Sawada, Susumu S. (2014). Physical fitness for health. Journal of Physical Fitness and Sports Medicine, 3(4), 377-384. doi: 10.7600/ jpfsm.3.377.

Sharkey, Brian J., Gaskill, Steven E. (2007). Fitness $\&$ health. Sixth edition. Canada : Human Kinetics.

Sugandhi, Tri. (2012). Hubungan antara status gizi dengan tingkat kebugaran jasmani kelas XI SMK YPLP Perwira Purbalingga Tahun Ajaran 2011/2012. (Skripsi, Universitas Negeri Yogyakarta. Diakses dari http://eprints.uny. ac.id/76935/.

Suntoda S, Andi. (2009). Tes, pengukuran, dan evaluasi dalam cabang olahraga. Makalah dipresentasikan pada Penataran Nasional Pengembangan Model Pembelajaran dan Perencanaan Penyusunan Program Latihan Softball se Jawa Barat dan Banten, Bandung. Diakses dari http:// file.upi.edu/Direktori/FPOK/JUR._PEND. OLAHRAGA/195806201986011.

Williams, Clyde., Rollo, Ian. (2015). Carbohydrate nutrition and team sport performace. Sports Medicine 45(1), 13-22. doi:10.1007/s40279015-0399-33. 